\title{
e Ozone Therapy as a Treatment for Low Back Pain Secondary to Herniated Disc: A Systematic Review and Meta-analysis of Randomized Controlled Trials
}

Francisco N. De Oliveira Magalhaes, MD, Luciana Dotta, MD, Andre Sasse, PhD, Manoel J. Teixeira, MD, PhD, and Erich T. Fonoff, MD, PhD

From: Hospital das Clínicas University of Sao Paulo Medical School, São Paulo, Brazil.

Dr. Magalhaes, Dr. Teixeria and Dr. Fonoff are with the Pain Center and Division of Functional, Neurosurgery Institute of Psychiatry of Hospital das Clínicas, Department of Neurology University of Sao Paulo Medical School, São Paulo, Brazil.

Dr. Dotta is with the Realinitation and

Phisiatric Discipline, Department of

Ortopedics, Hospital das Clínicas, University of Sao Paulo Medical School, São Paulo, Brazil.

Dr. Sasse is with the Department of Surgery, Medical Sciences School, State

University of Campinas - UNICAMP,

Campinas, São Paulo.

Address correspondence:

Erich T. Fonoff, MD, PhD

Pain Center and Division of Functional Neurosurgery Institute of Psychiatry of Hospital das Clínicas

Department of Neurology - University of Sao Paulo Medical School São Paulo, Brazil E-mail: fonoffet@usp.br

Disclaimer: This article was partially funded by $F$ APESP - Grant \#2011/08529-5

Conflict of interest: None.

Manuscript received: 09/08/2011 Revised manuscript received: 11/01/2011 Accepted for publication: 11/10/2011

Free full manuscript: www.painphysicianjournal.com
Background: Low back pain (LBP) is one of the most common and important health problems affecting the population worldwide and remains mostly unsolved. Ozone therapy has emerged as an additional treatment method. Questions persist concerning its clinical efficacy.

Objective: The purpose of our study was to evaluate the therapeutic results of percutaneous injection of ozone for low back pain secondary to disc herniation.

Study Design: A systematic review and meta-analysis of randomized controlled trials.

Methods: A comprehensive literature search was conducted using all electronic databases from 1966 through September 2011. The quality of individual articles was assessed based on the modified Cochrane review criteria for randomized trials and criteria from the Agency for Healthcare Research and Quality.

Outcome Parameters: The outcome measure was short-term pain relief of at least 6 months or long-term pain relief of more than 6 months.

Results: Eight observational studies were included in the systematic review and 4 randomized trials in the meta-analysis. The indicated level of evidence for long-term pain relief was II-3 for ozone therapy applied intradiscally and II-1 for ozone therapy applied paravertebrally. The grading of recommendation was 1C for intradiscal ozone therapy and 1B for paravertebral ozone therapy.

Limitations: The main limitations of this review are the lack of precise diagnosis and the frequent use of mixed therapeutic agents. The meta-analysis included mainly active-control trials. No placebo-controlled trial was found.

Conclusions: Ozone therapy appears to yield positive results and low morbidity rates when applied percutaneously for the treatment of chronic low back pain.

Key words: Low back pain, oxygen-ozone, ozone therapy, chronic pain, failed back surgery syndrome.

Pain Physician 2012; 15:E115-E129 ow back pain (LBP) is one of the most common and important clinical, social, economic, and public Thealth problems affecting the human population worldwide (1). Around $70 \%$ of adults suffer from LBP at some point in their lifetime with various degrees of symptom severity. Additionally, $1.6 \%$ to $43 \%$ of these patients have LBP associated with sciatic symptoms (2). In the United States, the incidence of chronic low back pain ranges from $15 \%$ to $45 \%$, with a prevalence of $30 \%$ (1). Most back pain has no recognizable cause 
on imaging studies and is usually attributed to muscle strain or ligament injuries (65\%-70\%). In 5\% to $15 \%$ of cases, the source of LBP is related to degenerative joints and disc disease (3). The natural history of disk herniation is favorable; improvement of symptoms is the norm, and most episodes resolve spontaneously or after conservative therapy. However, studies have shown that low back pain is sometimes still present after long periods of time (at least 12 months) in $37 \%$ to $54 \%$ of patients $(1,2)$.

Besides oral pharmacological and rehabilitation treatments, ozone therapy has emerged as an alternative or additional treatment option for these patients, particularly in Europe $(4,5)$. Despite its widespread use to treat a variety of conditions, ozone therapy remains unknown to most physicians. Ozone (O3) is an allotropic form of oxygen, primarily known for its ecological properties, industrial application and therapeutic effects. Questions persist concerning its potential toxicity as an oxidant agent versus its reported clinical efficacy. Several mechanisms of action have been proposed to explain the efficacy of ozone therapy including analgesic, anti-inflammatory and oxidant action on proteoglycans (e.g., in the nucleus pulposus). Ozone is administered in the form of an oxygen-ozone gas mixture at nontoxic concentrations ranging from 1 to $40 \mu \mathrm{g}$ of ozone per $\mathrm{mL}$ of oxygen, using various percutaneous methods (5).

Percutaneous techniques minimize the invasive nature of surgery, rendering administration more straightforward and faster while sparing healthy tissue and avoiding or minimizing complications such as postsurgical infection (6). Those techniques have been applied as an adjunct treatment for LBP and used in association with ozone injections have yielded good results (4). However, the effectiveness of ozone injections for the treatment of LBP remains a matter of debate. In order to investigate the effectiveness and safety of ozone therapy for this specific purpose, the authors performed a systematic review and metaanalysis of the literature, focusing on observational studies and randomized controlled trials (RCTs) in patients with subacute or chronic LBP.

\subsection{Methodology}

The methodology utilized in this work follows the systematic review process derived from evidence-based systematic review and meta-analysis of randomized trials (7) and the PRISMA statement (8).

\subsection{Inclusion Criteria}

\subsubsection{Types of Studies}

Three review authors screened the abstracts of studies in all languages against the inclusion criteria. They then retrieved all possibly relevant articles in full text for comprehensive assessment of the quality and satisfaction of inclusion criteria.

The review focused on randomized trials, systematic reviews, observational studies, and reports of complications. All studies providing appropriate management with outcome evaluations at 6 months or longer and statistical evaluations were reviewed. Reports without appropriate diagnosis, nonsystematic reviews, book chapters, and case series with fewer than 10 patients were excluded from the initial search in the databases.

\subsubsection{Types of Participants}

Participants were adults aged at least 18 years with low back pain due to lumbar disc herniation or degenerative disc disease treated by the interventional procedures 2.1.3 below.

\subsubsection{Types of Interventions}

Interventions were injections of an oxygen-ozone mixture associated or compared with steroids, and local anesthetic applied to intradiscal, intramuscular paraspinal, justaforaminal, periganglionic or epidural, guided by fluoroscopy or tomography.

\subsubsection{Types of Outcome Measures}

The primary outcome measure was pain relief (short term $<6$ months and long-term > 6 months) in accordance with Staal et al (9).

\subsection{Review criteria}

The search in the databases was performed independently by 3 authors who selected the articles for analysis. Each study was evaluated by 3 physicians for stated criteria and any disagreement was resolved by a fourth physician. The other author was responsible for statistical analysis.

\subsection{Adverse Events or Side Effects}

Adverse effects and complications were analyzed according to the description of the authors or based on case reports.

\subsection{Search Methods for Study Identification}

Searches were performed from the following sources: 
1. PubMed from 1966

www.ncbi.nlm.nih.gov/sites/entrez?db=pubmed

2. EMBASE from 1980

www.embase.com/

3. Cochrane Library

www.thecochranelibrary.com/view/0/index.html

4. DARE and HTA

Search period included from 1966 through September 2011.

\subsubsection{Search Strategy}

The search terminology included the terms ozonetherapy, ozone, ozone therapy, chronic low back pain, back pain, pain, failed back surgery syndrome and ozonucleolysis.

At least 3 of the review authors independently, in a standardized manner, performed each search. Accuracy was confirmed by a statistician. All searches were combined to obtain a unified search strategy. Any disagreements between reviewers were resolved by a third author and consensus.

\subsubsection{Assessment of Methodological Quality}

The methodological quality assessment was performed by 3 reviewers and any discrepancies were evaluated by a fourth reviewer and consensus was reached.

The quality of each individual article included in this analysis was assessed by modified Cochrane review criteria with weighted scores (10) for randomized trials and the Agency for Healthcare Research and Quality (AHRQ) quality criteria for assessment of observational studies (11). Only the observational studies scoring at least 50 on weighted scoring criteria were included for analysis. Methodological quality assessment criteria are described in Tables 1 and 2.

\subsection{Data Extraction and Management}

Three review authors independently extracted the data from the included studies. Disagreements were re- solved by discussion among the 3 review authors; if no agreement could be reached, it was planned a fourth author would decide.

\subsection{Measurement of Treatment Effect and Data Synthesis (Meta-analysis)}

The authors used a standardized data extraction form for independent inclusion of the study population, intervention, study design, and outcome measures for randomized controlled trials. The meta-analysis was performed using the Review Manager 5.0 (The Nordic Cochrane Centre, The Cochrane Collaboration, Copenhagen, Denmark) with the random-effect model. Dichotomous data were compared using odds ratio (OR). Respective $95 \%$ confidence intervals $(\mathrm{Cl})$ were calculated for each estimate and presented in forest plots. The pooled OR, symbolized by a solid diamond at the bottom of the forest plot (the width of which represents the $95 \% \mathrm{Cl}$ ), is the best estimate of the true (pooled) outcome. The effect of the treatment was expressed as a ratio of the ozone therapy arm over the control arm.

\subsection{Analysis of Evidence}

Analysis was conducted using 5 levels of evidence, ranging from Level I to III with 3 subcategories in level II, as illustrated in Table 1(12).

\subsection{Recommendations}

Grading recommendations were based on the criteria stated by Guyatt et al (13) as illustrated in Table 2.

\subsection{Outcomes of the Studies}

A study was judged positive if the ozone injections were clinically relevant and effective. Regarding randomized studies, this indicates that the difference in the effect for the primary outcome measure was statistically significant on the conventional $5 \%$ level. In a negative study, no difference between the studied group and the controls or no improvement from baseline was reported (9).

Table 1. Levels of evidence based on the Quality data available in the literature (USPSTF).

\begin{tabular}{|l|l|}
\hline \hline I: & Evidence obtained from multiple properly conducted diagnostic accuracy studies. \\
\hline II-1: & Evidence obtained from at least one properly conducted diagnostic accuracy study of adequate size. \\
\hline II-2: & Evidence obtained from at least one properly designed small diagnostic accuracy study. \\
\hline II-3: & Evidence obtained from diagnostic studies of uncertainty. \\
\hline III: & $\begin{array}{l}\text { Opinions of respected authorities, based on clinical experience descriptive studies Evidence obtained from case reports or reports of } \\
\text { expert committees. }\end{array}$ \\
\hline
\end{tabular}

Adapted and modified from the U.S. Preventive Services Task Force (USPSTF)(12). 
Table 2. Grading of recommendation

\begin{tabular}{|c|c|c|c|}
\hline $\begin{array}{c}\text { Grade of } \\
\text { Recommendation/ } \\
\text { Description }\end{array}$ & $\begin{array}{c}\text { Benefit vs. Risk and } \\
\text { Burdens }\end{array}$ & $\begin{array}{l}\text { Methodological Quality of } \\
\text { Supporting Evidence }\end{array}$ & Implications \\
\hline $\begin{array}{l}1 \mathrm{~A} / \text { strong } \\
\text { recommendation, high } \\
\text { quality evidence }\end{array}$ & $\begin{array}{l}\text { Benefits clearly outweigh } \\
\text { risk and burdens, or vice } \\
\text { versa }\end{array}$ & $\begin{array}{l}\text { RCTs without important limitations } \\
\text { or overwhelming evidence from } \\
\text { observational studies }\end{array}$ & $\begin{array}{l}\text { Strong recommendation, can apply to most } \\
\text { patients in most circumstances without } \\
\text { reservation }\end{array}$ \\
\hline $\begin{array}{l}1 \mathrm{~B} / \text { strong } \\
\text { recommendation, } \\
\text { moderate quality } \\
\text { evidence }\end{array}$ & $\begin{array}{l}\text { Benefits clearly outweigh } \\
\text { risk and burdens, or vice } \\
\text { versa }\end{array}$ & $\begin{array}{l}\text { RCTs with important limitations } \\
\text { (inconsistent results, } \\
\text { methodological flaws, indirect, or } \\
\text { imprecise) or exceptionally strong } \\
\text { evidence from observational studies }\end{array}$ & $\begin{array}{l}\text { Strong recommendation, can apply to most } \\
\text { patients in most circumstances without } \\
\text { reservation }\end{array}$ \\
\hline $\begin{array}{l}1 \mathrm{C} / \text { strong } \\
\text { recommendation, } \\
\text { low-quality or very low- } \\
\text { quality evidence }\end{array}$ & $\begin{array}{l}\text { Benefits clearly outweigh } \\
\text { risk and burdens, or vice } \\
\text { versa }\end{array}$ & Observational studies or case series & $\begin{array}{l}\text { Strong recommendation but may change } \\
\text { when higher quality evidence becomes } \\
\text { available }\end{array}$ \\
\hline $\begin{array}{l}2 \mathrm{~A} / \text { weak } \\
\text { recommendation, high- } \\
\text { quality evidence }\end{array}$ & $\begin{array}{l}\text { Benefits closely balanced } \\
\text { With risks and burden }\end{array}$ & $\begin{array}{l}\text { RCTs without important limitations } \\
\text { or overwhelming evidence from } \\
\text { observational studies }\end{array}$ & $\begin{array}{l}\text { Weak recommendation, best action may } \\
\text { differ depending on circumstances or } \\
\text { patients' or societal values }\end{array}$ \\
\hline $\begin{array}{l}\text { 2B/weak } \\
\text { recommendation, } \\
\text { moderate quality } \\
\text { evidence }\end{array}$ & $\begin{array}{l}\text { Benefits closely balanced } \\
\text { With risks and burden }\end{array}$ & $\begin{array}{l}\text { RCTs with important } \\
\text { limitations (inconsistent results, } \\
\text { methodological flaws, indirect, or } \\
\text { imprecise) or exceptionally strong } \\
\text { evidence from observational studies }\end{array}$ & $\begin{array}{l}\text { Weak recommendation, best action may } \\
\text { differ depending on circumstances or } \\
\text { patients' or societal values }\end{array}$ \\
\hline $\begin{array}{l}2 \mathrm{C} / \text { weak } \\
\text { recommendation, } \\
\text { low-quality or very low- } \\
\text { quality evidence }\end{array}$ & $\begin{array}{l}\text { Uncertainty in the estimates } \\
\text { of benefits, risks, and burden; } \\
\text { benefits, risk, and burden may } \\
\text { be closely balanced }\end{array}$ & Observational studies or case series & $\begin{array}{l}\text { Very weak recommendations; other } \\
\text { alternatives may be equally reasonable }\end{array}$ \\
\hline
\end{tabular}

Adapted from Guyatt et al. grading strength of recommendations and quality of evidence in clinical guidelines. Report from an American College of Chest Physicians task force (13)

\subsection{Results}

Our search strategy yielded multiple studies evaluating the effectiveness of ozone injected into the disc and/or periforaminal or at the paravertebral muscles. From the initial search (117 articles) only 35 were reviewed: 30 studies, including 7 randomized trials (1420) and 23 observational studies, and 5 reports of complications (21-25) (Fig. 1).

\subsection{Randomized Trials}

\subsubsection{Methodological Quality Assessment}

From the 7 randomized trials, 4 (14-17) met the established inclusion criteria. Three of them were excluded from the meta-analysis: one utilized colagenase (19) associated with ozone and steroid; Gautam et al (20) utilized intradiscal radiofrequency with ozone, and the other due to methodological issues that would invalidate the meta-analysis (18). The results of the methodological quality assessment of randomized studies are illustrated in Table 3. The quality assessment criteria ranged from 56 to 84 points for evidence synthesis.

\subsubsection{Descriptive results of randomized studies}

In the randomized series of 306 patients, Bonetti et al (14) reported that $57.5 \%$ of 80 patients in the disc disease group treated with steroid deemed the clinical outcome to be excellent, as did $62.8 \%$ of 70 patients in the group with no disc disease after steroid infiltration (Table 4). Whereas in the ozone therapy group, $74.4 \%$ of 86 patients with disc disease reported complete remission of pain, as did $75.0 \%$ of 70 patients with no disc disease. In this study, differences in favor of $02-03$ treatment were statistically significant in patients with disc disease but not in those without disc disease. In another randomized study, Gallucci et al (16) observed a satisfactory success rate with ozone-therapy combined with intraforaminal and intradiscal steroid and anesthetic injection compared to steroid alone. 


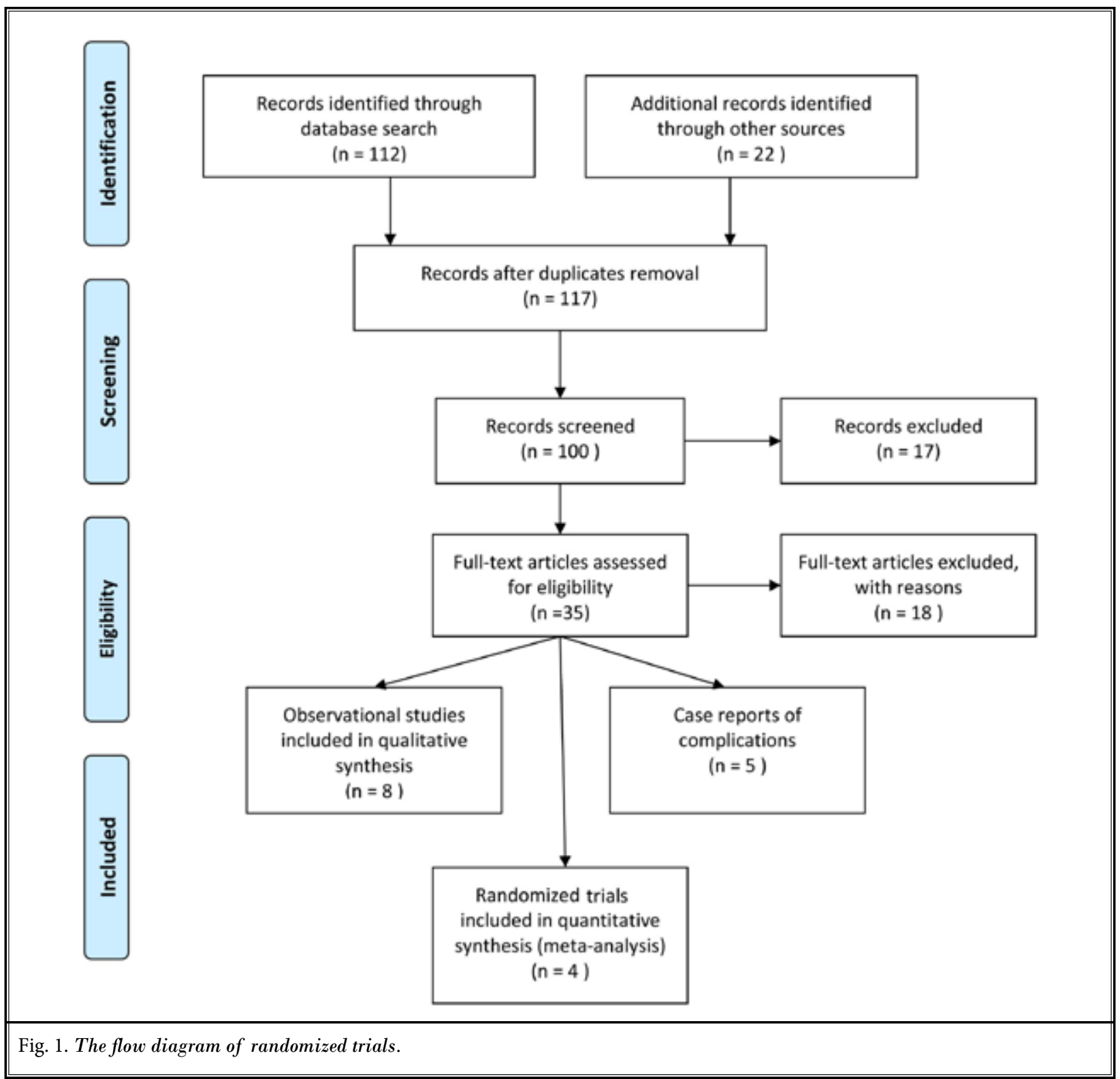

Zambello et al (15) randomized 351 patients with low back pain for treatment with either ozone or steroid (epidural) and planned a crossover during the follow-up to the other group in case of failure to respond to treatment after 4 weeks of therapy. The long-term outcome remained excellent or good in $47.3 \%$ of 171 patients treated by epidural steroid injections and in $77.1 \%$ of 180 patients treated with $02-03$. Eleven patients in the ozone group were subjected to crossover to epidural steroid injections whereas 38 patients in the epidural group were submitted to crossover to the ozone group. Only $36.4 \%$ of patients in the crossover group to epidural injection presented excellent/good remission of pain while $70.8 \%$ of patients in the epidural group who were submitted to crossover to ozone therapy reported an excellent/good outcome.

Recently, Paoloni et al (17) conducted a multicenter, randomized, double-blind, "simulated therapy"-controlled clinical trial. Thirty-six patients received intramuscular-paravertebral ozone injections whereas 24 received simulated lumbar intramuscular-paravertebral injections. The simulated injection was administered us- 
Table 3. Randomized trials on the efficacy of ozone therapy for low-back pain.

\begin{tabular}{|c|c|c|c|c|c|c|}
\hline & \multirow{2}{*}{ Criteria } & \multirow{2}{*}{$\begin{array}{l}\text { Criterion } \\
\text { weight }\end{array}$} & \multicolumn{4}{|c|}{$\begin{array}{l}\text { Scores for methods criteria } \\
\text { Author/Country/Year }\end{array}$} \\
\hline & & & $\begin{array}{c}\text { Paoloni } \\
(\mathbf{1 8}) / \\
\text { Italy/2009 }\end{array}$ & $\begin{array}{c}\text { Bonetti } \\
(\mathbf{1 5}) / \\
\text { Italy/2005 }\end{array}$ & $\begin{array}{c}\text { Gallucei } \\
(\mathbf{1 7}) / \\
\text { Italy/2007 }\end{array}$ & $\begin{array}{c}\text { Zambello } \\
\text { (16)/ } \\
\text { Italy/2006 }\end{array}$ \\
\hline \multicolumn{7}{|c|}{ Study population } \\
\hline A & Homogeneity & 2 & 2 & 2 & 2 & 2 \\
\hline B & $\begin{array}{l}\text { Comparability of relevant baseline } \\
\text { characteristics }\end{array}$ & 5 & 5 & 5 & 5 & - \\
\hline $\mathrm{C}$ & Randomization procedure adequate & 4 & 4 & - & - & - \\
\hline $\mathrm{D}$ & $\begin{array}{l}\text { Drop-outs described for each study group } \\
\text { separately }\end{array}$ & 3 & 3 & - & - & 3 \\
\hline \multirow[t]{2}{*}{$\mathrm{E}$} & $<20 \%$ loss to follow-up & 2 & 2 & - & - & - \\
\hline & $<10 \%$ loss to follow-up & 2 & & & & \\
\hline \multirow[t]{2}{*}{$\mathrm{F}$} & $>50$ subjects in the smallest group 8 & & & & & \\
\hline & $>100$ subjects in the smallest group & 9 & 8 & 8 & 8 & 9 \\
\hline \multicolumn{7}{|c|}{ Interventions } \\
\hline G & $\begin{array}{l}\text { Interventions included in protocol and } \\
\text { described }\end{array}$ & 10 & 10 & 10 & 10 & 10 \\
\hline $\mathrm{H}$ & Pragmatic study & 5 & 5 & 5 & 5 & 5 \\
\hline I & Co-interventions avoided & 5 & 5 & 5 & 5 & 5 \\
\hline $\mathrm{J}$ & Placebo-controlled & 5 & - & - & - & - \\
\hline \multicolumn{7}{|c|}{ Effect } \\
\hline $\mathrm{K}$ & Patients blinded & 5 & 5 & 5 & - & - \\
\hline $\mathrm{L}$ & Outcome measures relevant & 10 & 10 & 10 & 10 & 10 \\
\hline M & Blinded outcome assessments & 10 & 10 & 10 & - & - \\
\hline $\mathrm{N}$ & Follow-up period adequate & 5 & 5 & 5 & 5 & 5 \\
\hline \multicolumn{7}{|c|}{ Data-presentation and analysis } \\
\hline $\mathrm{O}$ & Intention-to-treat analysis & 5 & 5 & - & - & - \\
\hline $\mathrm{P}$ & $\begin{array}{l}\text { Frequencies of most important outcomes } \\
\text { presented for each treatment group. }\end{array}$ & 5 & 5 & 5 & 5 & 5 \\
\hline \multicolumn{2}{|c|}{ Total Score } & & 84 & 70 & 70 & 56 \\
\hline
\end{tabular}

Methodological criteria and scoring adapted from Koes et al (10). Efficacy of epidural steroid for low-back pain and sciatica: A systematic review of randomized clinical trials.

ing a false needle that pricked the skin without piercing it, applied at the lumbar paraspinal level, followed by hand-applied pressure on the same site designed to reproduce the load sensation commonly described after $\mathrm{O} 2-\mathrm{O} 3$ injections. Patients who received ozone had significant lower pain scores (mean visual analog scale
[VAS] was 0.66 in the study group and 4.00 in the control group) compared to patients who received simulated therapy. Also, a greater percentage of patients became pain-free $(61 \%$ versus $33 \%, P<0.01)$ in the ozone group. Active ozone therapy was followed by a statistically significant shorter time on nonsteroidal an- 
Table 4. Results of randomized studies of ozone therapy for low-back pain

\begin{tabular}{|c|c|c|c|c|}
\hline $\begin{array}{c}\text { Author/ } \\
\text { Country/ } \\
\text { Year / } \\
\text { Methods/ } \\
\text { Type of pain }\end{array}$ & Participants & $\begin{array}{c}\text { Design of study / } \\
\text { Intervention(s) (guided } \\
\text { by CT or fluoroscopy) }\end{array}$ & Outcome(s) & Result(s) \\
\hline $\begin{array}{l}\text { Bonetti (15), } \\
\text { Italy, 2005, } \\
\text { RA, DB }\end{array}$ & $\begin{array}{l}306 \text { patients with acute } \\
\text { or chronic low back pain } \\
\text { and sciatic nerve pain } \\
\text { were treated. They were } \\
\text { divided into two groups: } \\
\text { Group with disc disease } \\
\text { (bulging disk, protrusion or } \\
\text { extrusion; } n=166 \text { ); group with } \\
\text { non-disc vertebral disease } \\
\text { (osteophytosis, spondylolysis, } \\
\text { facet joint syndrome; } n=140 \text { ) } \\
\text { and received ozone or steroid } \\
\text { infiltrations. }\end{array}$ & $\begin{array}{l}\text { The patients were divided } \\
\text { into two groups with their } \\
\text { subgroups: injections were } \\
\text { infiltrated adjacent to neural } \\
\text { foramina or facet joint regions } \\
\text { guided by CT. } \\
\text { G1=Ozone }(7 \mathrm{~mL}-25 \mu \mathrm{g} / \mathrm{mL}) \text { : } \\
\text { With disc disease: } \mathrm{n}=86 \\
\text { Non-disc disease: } \mathrm{n}=70 \\
\text { G2=(Steroid): } \\
\text { With disc disease: } \mathrm{n}=80 \\
\text { Non-disc disease: } \mathrm{n}=70\end{array}$ & $\begin{array}{l}\text { Timing: } 1 \text { week, } 3 \text { and } 6 \\
\text { months. } \\
\text { Outcome measures: } \\
\text { (MacNab } \\
\text { Score): } \\
\\
\text { Excellent: pain free and } \\
\text { return to work } \\
\text { Good: Pain relief } 50 \% \text { or } \\
\text { more } \\
\text { Poor: Pain relief } 30 \% \text { or } \\
\text { less. }\end{array}$ & 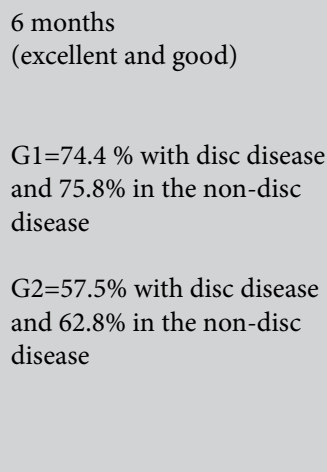 \\
\hline $\begin{array}{l}\text { Galluci17, Italy, } \\
2007, \\
\text { RA, DB }\end{array}$ & $\begin{array}{l}159 \text { patients with lumbar disc } \\
\text { herniation and radicular pain. } \\
\text { All patients complained of } \\
\text { pain for at least } 8 \text { weeks with } \\
\text { poor clinical improvement } \\
\text { after conservative treatment. }\end{array}$ & $\begin{array}{l}\text { The patients were divided } \\
\text { into two groups: all received } \\
\text { intradiscal and intraforaminal } \\
\text { injections of a steroid and } \\
\text { a local anesthetic or ozone } \\
(7 \mathrm{~mL}-28 \mu \mathrm{g} / \mathrm{mL}) \text {. } \\
\text { G1(n=82) Steroid / local } \\
\text { anesthetic } \\
\text { G2(n=77)Steroid / local } \\
\text { anesthetic and ozone }\end{array}$ & $\begin{array}{l}\text { Timing: } 2 \text { weeks, } 3 \text { and } 6 \\
\text { months; } \\
\text { Outcome measures: } \\
\text { Classified as successful if } \\
\text { the Oswestry Disability } \\
\text { Index was no greater than } \\
20 \% \text { at follow up and } \\
\text { unsuccessful otherwise. }\end{array}$ & $\begin{array}{l}6 \text { months } \\
\text { Successful: } \\
\text { G1 }=47 \% \\
\text { G2 }=74 \% \\
\text { Unsuccessful: } \\
\text { G1 }=53 \% \\
\text { G2 }=26 \%\end{array}$ \\
\hline $\begin{array}{l}\text { Paoloni18, } \\
\text { Italy, 2009, } \\
\text { RA, DB }\end{array}$ & $\begin{array}{l}60 \text { patients with acute low } \\
\text { back pain and/or radiating } \\
\text { pain of moderate to severe } \\
\text { intensity (VAS } \geq 5 \text { ) and MRI } \\
\text { evidence of disc protrusion } \\
\text { with or without disc } \\
\text { degeneration in the spinal } \\
\text { segments involved in the pain. }\end{array}$ & $\begin{array}{l}\text { The patients were divided } \\
\text { into two groups: } \\
\text { G1(n=36): Ozone } \\
\text { intramuscular paravertebral } \\
\text { lumbar infiltrations ( } 3 / \text { wk for } \\
5 \text { consecutive weeks) of ozone } \\
(20 \mathrm{~mL}-20 \mu \mathrm{g} / \mathrm{mL}) \text {. } \\
\text { G2(n=24): Simulated therapy: } \\
\text { injection using a false needle } \\
\text { that pricked the skin without } \\
\text { piercing it, pressure applied } \\
\text { at the lumbar paravertebral } \\
\text { level. }\end{array}$ & $\begin{array}{l}\text { Timing: } 15 \text { and } 30 \text { days, } 2 \\
\text { weeks, } 3 \text { and } 6 \text { months. } \\
\text { Outcome measures: (at the } \\
\text { end of follow up) } \\
\text { Pain free on VAS score } \leq \\
\text { 1, Backill questionnaire, } \\
\text { SF-36, Kellner scores. }\end{array}$ & $\begin{array}{l}6 \text { months } \\
\text { Pain-free: } \\
\text { G1 }=61 \% \\
\text { G2=33\% } \\
\text { Backill score: } \\
\text { G1=+13.0 } \\
\text { G2=+5.6 } \\
\text { Kellner and SF-36: } \\
\text { No differences between } \\
\text { groups } \\
\text { MRI findings: } \\
\text { Unchanged } \\
\text { Drug intake: } \\
\text { Decreased }\end{array}$ \\
\hline $\begin{array}{l}\text { Zambello16, } \\
\text { Italy, 2006, } \\
\text { RA, DB }\end{array}$ & $\begin{array}{l}351 \text { patients with chronic } \\
\text { irradiating low back pain over } \\
\text { sciatic nerve and failure to } \\
\text { respond to medical treatment } \\
\text { were randomly assigned to } \\
\text { one of two groups. }\end{array}$ & $\begin{array}{l}\text { The patients were divided } \\
\text { into two groups: } \\
\text { G1(n=171): Steroid at } \\
\text { intervertebral space } \\
\text { G2(n=180): Ozone into } \\
\text { the paravertebral muscle, } \\
5 \mathrm{~mL}-20 \mu \mathrm{g} / \mathrm{mL})\end{array}$ & $\begin{array}{l}\text { Timing: } 3 \text { weeks and } 6 \\
\text { months; } \\
\text { Outcome measures: } \\
\text { Subjective pain scores } \\
\text { (MacNab method } \\
\text { Score). }\end{array}$ & $\begin{array}{l}6 \text { months } \\
\text { (excellent or good) } \\
\text { G1 }=47.3 \% \text { and } 77.1 \%\end{array}$ \\
\hline
\end{tabular}

$\mathrm{G} 1$ = group 1; G2 = group 2; G3 = group 3; G4 = group 4; WK = week; RA = randomized; $\mathrm{P}=$ prospective; $\mathrm{O}=$ observational; $\mathrm{DB}=$ double blinded; $\mathrm{B}=$ blinded (patients or evaluator); $\mathrm{U}$ = unblended; $\mathrm{R}$ = retrospective; $\mathrm{CT}$ = tomography; VAS = Visual Analog Scale; MacNab method (excellent and good outcome); MRI/MR (magnetic resonance imaging). 
ti-inflammatory drugs, as well as a significant improvement on the disability scale in the patient study group compared to the controls.

The outcome measures of the randomized studies were VAS (17,20), Backill scores (17) and drug intake( 17), MacNab's criteria $(15,20)$, and ODI $(16,20)$.

\subsection{Observational Studies}

\subsubsection{Methodological Quality Assessment}

A total of 23 observational studies were considered for inclusion (Fig. 1). Only 8 of these met the methodological quality assessment criteria for inclusion (Table 5) (26-33). The results of the methodological quality assessment showed scores from 50 to 72 . Some observational studies met the inclusion criteria, but had an insufficient score in the methodological quality assessment, and thus were only listed in the references (34-46). Furthermore, some studies were excluded for other reasons: one compared ozone therapy with a not well-established treatment (Alanerv) for low back pain (47); and Baabor et al (48) used another intervention associated with intradiscal ozone.

\subsubsection{Descriptive results of observational studies}

Among the observational studies, we observed heterogeneous groups of patients, different follow-up periods, and some discrepancy in the computed tomography $(\mathrm{CT})$ or magnetic resonance imaging (MRI) evaluations of morphological criteria (Table 6). Muto et al published 3 studies between 1998 and $2008(27,28,29)$ using intradiscal injection of an oxygen-ozone mixture under CT guidance to treat approximately 3,700 patients and reported an $80 \%$ success rate at short-term follow-up (6 months) and a $75 \%$ success rate at longterm follow-up (18 months), with no major or minor side effects.

Oder et al (26) studied 621 patients to determine associations among the morphology of the disc disease, patient-specific data, and treatment outcomes. Six hundred twenty-one consecutive patients were subjected to CT-guided ozonucleolysis in combination with periradicular infiltration by steroids under local anesthesia. Based on the MRI findings of the lumbar spine, the patients were retrospectively divided into 5 diagnostic groups: group I consisted of 205 patients (bulging disc); group II had 185 patients (herniated disc); group III had 66 patients (postoperative patients); group IV had 51 patients (primarily intervertebral osteochondrosis); and group V had 114 patients and included other primary nondiscal changes (intervertebral arthrosis, spinal canal stenosis and pseudoanterolisthesis). The patients received steroid and an oxygen-ozone mixture into the disc and periganglionic infiltrations by CT guidance. Each patient was monitored for a period of 6 months and documented with the Oswestry Disability Index (ODI) and VAS. Patients younger than 50 years had significantly better values on the VAS and in ODI scores, 6 months after treatment.

Andreula et al (30) reported a $78.3 \%$ success rate in patients treated with ozone therapy and periganglionic steroid injection compared with a $70.3 \%$ rate in those treated with ozone therapy alone; complications occurred in 2 of 235 patients and consisted of episodes of impaired sensitivity in the lower limb on the treated side, which resolved spontaneously within 2 hours. In a series of 45 patients, Buric et al (31) studied the differences in outcome between intradiscal ozone chemonucleolysis and microdiscectomy in patients with noncontained lumbar disc herniations; they documented that 27 patients $(90 \%)$ in the chemonucleolysis group showed a statistically significant improvement in pain and function; the same was true in $14(93.3 \%)$ patients in the microdiscectomy group. However, 2 patients dropped out of the ozone chemonucleolysis group because of aggravating symptoms and subsequently underwent surgery.

Das et al (33), in an Indian population cohort study, evaluated 53 consecutive patients with lumbar disc herniation. All presented with clinical signs of lumbar nerve root compression supported by CT and MRI findings. They were treated with a single session of intradiscal ozone therapy. Therapeutic outcome was assessed after 2 years. Pain intensity was significantly reduced following treatment (VAS baseline was 7.58; after 2 years, 2.64). Similar ODI results were seen $(P<0.05)$. No major complication was observed in this case series.

$\mathrm{Xu}$ et al (32) included 187 patients with sciatica and low back pain with positive Lasègue sign and diagnostic verification by $\mathrm{CT}$ and MRI exhibited disc protrusion with nerve root or thecal sac compression. They compared the effectiveness rates after one week (103 cases), 2 weeks ( 61 cases), and 4 weeks ( 23 cases) treatment sessions of intradiscal ozone therapy. They were evaluated by Macnab criteria at 48 months. The effective rate was $82.02 \%$ in all groups. However, there were no significant differences in the total effective rate in the 3 groups $(P=0.280)$. 
Ozone Therapy for Low Back Pain

Table 5. Methodological assessment of observational studies of ozone therapy

\begin{tabular}{|c|c|c|c|c|c|c|c|c|c|}
\hline \multirow[b]{2}{*}{ Criteria } & \multirow[b]{2}{*}{$\begin{array}{c}\text { Weighted } \\
\text { Core } \\
\text { Points }\end{array}$} & \multicolumn{8}{|c|}{ Author/country/year } \\
\hline & & $\begin{array}{c}\text { Oder } \\
\text { Austria } \\
\mathbf{2 0 0 8}\end{array}$ & $\begin{array}{l}\text { Muto } \\
\text { Italy } \\
2008\end{array}$ & $\begin{array}{l}\text { Muto } \\
\text { Italy } \\
2004\end{array}$ & $\begin{array}{c}\text { Andrula } \\
\text { Italy } \\
2003\end{array}$ & $\begin{array}{l}\text { Muto } \\
\text { Italy } \\
1998\end{array}$ & $\begin{array}{c}\text { Buric } \\
\text { Austria } \\
\mathbf{2 0 0 5}\end{array}$ & $\begin{array}{c}\text { Xu } \\
\text { China } \\
2009\end{array}$ & $\begin{array}{c}\text { Das } \\
\text { India } \\
2009\end{array}$ \\
\hline 1. Study Question & 2 & 2 & 2 & 2 & 2 & 2 & 2 & 2 & 2 \\
\hline Clearly focused and appropriate question & 2 & 2 & 2 & 2 & 2 & 2 & 2 & 2 & 2 \\
\hline 2. Study Population & 8 & 5 & 5 & 5 & 5 & 5 & 5 & 5 & 5 \\
\hline Description of study population & 5 & 5 & 5 & 5 & 5 & 5 & 5 & 5 & 5 \\
\hline Sample size justification & 3 & 0 & 0 & 0 & 0 & 0 & 0 & 0 & 0 \\
\hline 3. Comparability of subjects & 22 & 11 & 11 & 14 & 14 & 14 & 14 & 11 & 14 \\
\hline Specific inclusion/exclusion criteria for all groups & 5 & 5 & 5 & 5 & 5 & 5 & 5 & 5 & 5 \\
\hline Criteria applied equally to all groups & 3 & 3 & 3 & 3 & 3 & 3 & 3 & 3 & 3 \\
\hline $\begin{array}{l}\text { Comparability of groups at baseline with } \\
\text { regard to disease status and prognostic factors }\end{array}$ & 3 & 3 & 0 & 3 & 0 & 3 & 3 & 0 & 3 \\
\hline $\begin{array}{l}\text { Study groups comparable to non-participants } \\
\text { with regard to confounding factors }\end{array}$ & 3 & 0 & 0 & 0 & 0 & 0 & 0 & 0 & 0 \\
\hline Use of concurrent controls & 5 & 0 & 0 & 0 & 0 & 0 & 0 & 0 & 0 \\
\hline $\begin{array}{l}\text { Comparability of follow up among groups at } \\
\text { each assessment }\end{array}$ & 3 & 3 & 3 & 3 & 3 & 3 & 3 & 3 & 3 \\
\hline 4. Exposure or Intervention & 11 & 11 & 11 & 11 & 11 & 11 & 11 & 11 & 11 \\
\hline Clear definition of exposure & 5 & 5 & 5 & 5 & 5 & 5 & 5 & 5 & 5 \\
\hline Measurement method standard valid and reliable & 3 & 3 & 3 & 3 & 3 & 3 & 3 & 3 & 3 \\
\hline Exposure measure equally in all study groups & 3 & 3 & 3 & 3 & 3 & 3 & 3 & 3 & 3 \\
\hline 5. Outcome measures & 20 & 10 & 15 & 10 & 15 & 10 & 15 & 12 & 15 \\
\hline Primary/secondary outcome clearly defined & 5 & 0 & 5 & 0 & 0 & 5 & 5 & 2 & 5 \\
\hline $\begin{array}{l}\text { Outcomes assessed blind to exposure or } \\
\text { intervenient }\end{array}$ & 5 & 0 & 0 & 0 & 5 & 0 & 0 & 0 & 0 \\
\hline $\begin{array}{l}\text { Method of outcome assessment standard, valid } \\
\text { and reliable }\end{array}$ & 5 & 5 & 5 & 5 & 5 & 0 & 5 & 5 & 5 \\
\hline Length of follow-up adequate for question & 5 & 5 & 5 & 5 & 5 & 5 & 5 & 5 & 5 \\
\hline 6. Statistical Analysis & 19 & 17 & 0 & 0 & 0 & 0 & 8 & 7 & 10 \\
\hline Statistical tests appropriate & 5 & 5 & 0 & 0 & 0 & 0 & 5 & 5 & 5 \\
\hline Multiple comparisons taken into consideration & 3 & 3 & 0 & 0 & 0 & 0 & 3 & 0 & 3 \\
\hline Modeling and multivariate techniques appropriate & 2 & 2 & 0 & 0 & 0 & 0 & 0 & 0 & 2 \\
\hline Power calculation provided & 2 & 2 & 0 & 0 & 0 & 0 & 0 & 0 & 0 \\
\hline Assessment of confounding & 5 & 5 & 0 & 0 & 0 & 0 & 0 & 0 & 0 \\
\hline Dose-response assessment appropriate & 2 & 0 & 0 & 0 & 0 & 0 & 0 & 2 & 0 \\
\hline 7. Results & 8 & 8 & 8 & 8 & 5 & 3 & 8 & 8 & 8 \\
\hline $\begin{array}{l}\text { Measure of effect for outcomes and } \\
\text { appropriate measure of precision }\end{array}$ & 5 & 5 & 5 & 5 & 0 & 0 & 5 & 5 & 5 \\
\hline Adequacy of follow-up for each study group & 3 & 3 & 3 & 3 & 5 & 3 & 3 & 3 & 3 \\
\hline 8. Discussion & 5 & 5 & 0 & 0 & 0 & 5 & 5 & 3 & 5 \\
\hline $\begin{array}{l}\text { Conclusions supported by results with possible } \\
\text { biases and limitations taken into consideration }\end{array}$ & 5 & 5 & 0 & 0 & 0 & 5 & 5 & 3 & 5 \\
\hline 9. Funding or Sponsorship & 5 & 5 & 5 & 0 & 0 & 0 & 0 & 0 & 0 \\
\hline Type and sources of support for study & - & 0 & 0 & 0 & 0 & 0 & 0 & 0 & 0 \\
\hline TOTAL SCORE & 100 & 72 & 52 & 50 & 52 & 50 & 68 & 59 & 70 \\
\hline
\end{tabular}

West et al. Rating system to measure the strength of evidence, evidence report, technology assessment No. 47 AHQR Publication No. 02-016 (11). www.painphysicianjournal.com 
Table 6 . Results of observational studies of ozone therapy for low-back pain

\begin{tabular}{|c|c|c|c|c|c|}
\hline \multirow{2}{*}{$\begin{array}{c}\text { Author/ } \\
\text { Country/year/ } \\
\text { Methods/Type } \\
\text { of pain }\end{array}$} & \multirow[b]{2}{*}{ Participants } & \multirow[b]{2}{*}{$\begin{array}{c}\text { Design of study/intervention } \\
\text { (s) } \\
\text { (guided by CT or fluoroscopy) }\end{array}$} & \multirow[b]{2}{*}{ Outcome(s) } & \multicolumn{2}{|c|}{ Result(s) } \\
\hline & & & & $\begin{array}{c}\text { Short- } \\
\text { term } \\
(6 \text { mos.) }\end{array}$ & $\begin{array}{l}\text { Long-term } \\
(>6 \text { mos.) }\end{array}$ \\
\hline $\begin{array}{l}\text { Das (33), Índia, } \\
2009 \\
\text { Chronic }\end{array}$ & $\begin{array}{l}53 \text { patients with low back pain due to } \\
\text { lumbar disc prolapsed were included } \\
\text { in this study }\end{array}$ & Prospective cohort study & $\begin{array}{l}\text { Timing: } 2 \text { years } \\
\text { Measure } \\
\text { outcome: VAS } \\
\text { and ODI }\end{array}$ & - & $\begin{array}{l}\text { VAS } \\
\text { (improvement of } \\
\text { the } 65.17 \% \text { ) }\end{array}$ \\
\hline $\begin{array}{l}\text { Xu (32), China, } \\
2009 \\
\text { Chronic }\end{array}$ & $\begin{array}{l}187 \text { patients with diagnostically } \\
\text { confirmed lumbar disc herniation } \\
\text { with sciatica and low back pain }\end{array}$ & $\begin{array}{l}\text { Prospective study } \\
\text { G1: (103) One week session } \\
\text { G2: (61) } 2 \text {-week session } \\
\text { G3: (23) 4-week sessions }\end{array}$ & $\begin{array}{l}\text { Timing: } 48 \\
\text { mos. Outcome } \\
\text { measures: } \\
\text { MacNab's criteria }\end{array}$ & $\begin{array}{l}\text { Not } \\
\text { reported }\end{array}$ & $\begin{array}{l}\text { G1: } 82.52 \% \\
\text { G2. } 85.24 \% \\
\text { G3: } 95.65 \%\end{array}$ \\
\hline $\begin{array}{l}\text { Muto (29), } \\
\text { Italy, 2008 } \\
\text { R, O } \\
\text { Subacute }\end{array}$ & $\begin{array}{l}\text { In } 6 \text { years, } 2,900 \text { patients with low } \\
\text { back pain and/or sciatica refractory } \\
\text { to medical management, lasting } \\
\text { at least } 2-3 \text { mos. were treated with } \\
\text { ozone and selected on the basis of } \\
\text { clinical, psychological, neurological } \\
\text { and neuroradiological criteria. }\end{array}$ & $\begin{array}{l}\text { Patients divided into } 4 \text { groups: all } \\
\text { procedures were carried out with: } \\
\text { ozone }(40 \mu \mathrm{g} / \mathrm{mL}) \text { intradiscal }(3- \\
4 \mathrm{~mL}) \text { and the foramen }(10 \mathrm{~mL}) \\
\text { G1 }(\mathrm{n}=2.650 \text { with soft }- \text { disc } \\
\text { herniation; } \mathrm{G} 2(\mathrm{n}=250) \text { had } \\
\text { calcified herniation; } \mathrm{G} 3(\mathrm{n}=350) \\
\text { had multiple herniation and } \\
\text { G4 }(\mathrm{n}=200) \text { had FBSS }\end{array}$ & $\begin{array}{l}\text { Timing: } 6 \text { and } \\
12 \text { mos. } \\
\text { Outcome } \\
\text { measure: } \\
\text { VAS (-3 pts), } \\
\text { MacNab's } \\
\text { criteria and } \\
\text { ODI (-30\%) }\end{array}$ & $\begin{array}{l}\text { Not } \\
\text { reported }\end{array}$ & $\begin{array}{l}12 \text { mos. } \\
\text { (excellent and } \\
\text { good) VAS: } 85 \% \\
\text { ODI: Significant } \\
\text { reduction } \\
\text { G1 }=75 \% \\
\text { G2 }=\text { Not } \\
\text { reported } \\
\text { G3 }=77 \% \\
\text { G4 }=60 \%\end{array}$ \\
\hline $\begin{array}{l}\text { Oder (26), } \\
\text { Austria, } 2008 \\
\text { R, O } \\
\text { Chronic }\end{array}$ & $\begin{array}{l}621 \text { patients with lumbago or } \\
\text { lumboischialgia and degenerative } \\
\text { disease of the lumbar spine whose } \\
\text { symptoms did not improve after } \\
\text { previous conservative procedure }\end{array}$ & $\begin{array}{l}\text { They were retrospectively divided } \\
\text { into } 5 \text { diagnosis groups: } \\
\text { G1 }(n=205) \text { Bulging disc; } \\
\text { G2 }(n=185) \text { herniated disc; } \\
\text { G3 } n=66) \text { post-operative patients; } \\
\text { G4 }(n=51) \text { ostheocondrosis and } \\
\text { G5 ( } n 114) \text { non-disc disease } \\
\text { (spinal canal stenosis, inter- } \\
\text { vertebral arthrosis and } \\
\text { pseudoanterolisthesis) }\end{array}$ & $\begin{array}{l}\text { Timing: } 2 \text { and } 6 \\
\text { mos. } \\
\text { Measure } \\
\text { outcome: VAS } \\
\text { and ODI }\end{array}$ & $\begin{array}{l}\text { Not } \\
\text { reported }\end{array}$ & $\begin{array}{l}6 \text { mos. (VAS) } \\
\text { All patients } \\
\text { improved: } \\
\text { VAS: } 31.8 \% \\
\text { ODI: Not } \\
\text { measured }\end{array}$ \\
\hline $\begin{array}{l}\text { Buric (31), } \\
\text { Italy, 2005 } \\
\text { P,O } \\
\text { Subacute }\end{array}$ & $\begin{array}{l}45 \text { patients with acute or sub acute } \\
\text { low back pain unresponsive to } \\
\text { pharmacological treatment }\end{array}$ & $\begin{array}{l}\text { The patients were divided into two } \\
\text { groups } \\
\text { G1 }(\mathrm{n}=30) \text { ozone inside the disc/30 } \\
\mathrm{ml}-30 \mu \mathrm{g} / \mathrm{ml} \\
\mathrm{G} 2(\mathrm{n} 15) \text { microdiscectomy }\end{array}$ & $\begin{array}{l}\text { Timing: } 6,12 \\
\text { and } 18 \text { mos. } \\
\text { Outcome } \\
\text { measures: } \\
\text { VAS, RMDQ, } \\
\text { OPSR. MRI } \\
\text { scans pre and } \\
\text { post- treatment }\end{array}$ & $\begin{array}{l}\text { Not } \\
\text { reported }\end{array}$ & $\begin{array}{l}18 \text { mos. } \\
\text { VAS (rate of } \\
\text { improvement) } \\
\text { G1=90\%; } \\
\text { G2=93.3\% } \\
\text { RMDQ: } \\
\text { G1=90\% } \\
\text { G2=8606\% } \\
\text { OPRS:G1 79.3\% } \\
\text { G2=82.1 } \% \\
\text { Morphological } \\
\text { changes: } 49 \% \\
\text { improved on } \\
\text { MRI scan } \\
\end{array}$ \\
\hline $\begin{array}{l}\text { Muto (28), } \\
\text { Italy, 2004 } \\
\text { R, O } \\
\text { Subacute }\end{array}$ & $\begin{array}{l}2,200 \text { patients with low back pain } \\
\text { and/or sciatica refractory to medical } \\
\text { management, lasting at least } 2-3 \\
\text { mos., subjects were treated with } \\
\text { ozone and selected on the basis of } \\
\text { clinical, psychological, neurological } \\
\text { and neuroradiological criteria. }\end{array}$ & $\begin{array}{l}\text { Consecutive patients with } \\
\text { degenerative disease, herniated } \\
\text { disc, multiple disc herniation, } \\
\text { FBSS, calcified disc herniation } \\
\text { and disc associated with spinal } \\
\text { stenosis received ozone }(40 \mu \mathrm{g} / \\
\mathrm{mL}) \text { intradiscal }(3-4 \mathrm{~mL}) \text { and the } \\
\text { foramen }(10 \mathrm{~mL}) \text {. }\end{array}$ & $\begin{array}{l}\text { Timing: } 6 \text { and } \\
18 \text { mos. } \\
\text { Outcome } \\
\text { measures: } \\
\text { Subjective } \\
\text { MacNab's } \\
\text { criteria }\end{array}$ & $\begin{array}{l}\text { Not } \\
\text { reported }\end{array}$ & $\begin{array}{l}6 \text { mos. } \\
\text { (excellent and } \\
\text { good) } \\
\mathrm{G} 1=70.3 \% \\
\mathrm{G} 2=78.3 \%\end{array}$ \\
\hline
\end{tabular}


Table 6 (cont.) . Results of observational studies of ozone therapy for low-back pain

\begin{tabular}{|c|c|c|c|c|c|}
\hline \multirow{2}{*}{$\begin{array}{c}\text { Author/ } \\
\text { Country/year/ } \\
\text { Methods/Type } \\
\text { of pain }\end{array}$} & \multirow[b]{2}{*}{ Participants } & \multirow{2}{*}{$\begin{array}{l}\text { Design of study/intervention } \\
\text { (s) } \\
\text { (guided by CT or fluoroscopy) }\end{array}$} & \multirow[b]{2}{*}{ Outcome(s) } & \multicolumn{2}{|c|}{ Result(s) } \\
\hline & & & & $\begin{array}{c}\text { Short- } \\
\text { term } \\
(6 \text { mos. }) \\
\end{array}$ & $\begin{array}{c}\text { Long-term } \\
(>6 \text { mos.) }\end{array}$ \\
\hline $\begin{array}{l}\text { Andreula (30), } \\
\text { Italy, } 1998 \\
\text { P, O, } \\
\text { Subacute }\end{array}$ & $\begin{array}{l}\text { 600patients with chronic low back } \\
\text { pain resistant to conservative } \\
\text { treatment, with positive sings } \\
\text { of nerve root involvement, with } \\
\text { or Without hypoesthesia or } \\
\text { paraesthesia, with appropriate } \\
\text { dermatome distribution and CT } \\
\text { or MRI findings in live with the } \\
\text { patient's clinical Picture }\end{array}$ & $\begin{array}{l}\text { The patients were divided in two } \\
\text { groups: } \\
\text { G1 }(\mathrm{n}=211) \text { ozone Intradiscal } / 4 \mathrm{ml} \\
\text { and periganglionic } / 8 \mathrm{ml}-30 \mu \mathrm{g} / \mathrm{ml} \\
\mathrm{G} 2(\mathrm{n}=235) \text { ozone + steroid }\end{array}$ & $\begin{array}{l}\text { Timing } 6 \text { mos. } \\
\text { Outcomes } \\
\text { measures: } \\
\text { Subjective } \\
\text { MacNab's } \\
\text { criteria }\end{array}$ & $\begin{array}{l}\text { Not } \\
\text { reported }\end{array}$ & $\begin{array}{l}6 \text { mos. } \\
\text { (excellent and } \\
\text { good } \\
\mathrm{G} 1=70.3 \% \\
\mathrm{G} 2=78.3 \%\end{array}$ \\
\hline $\begin{array}{l}\text { Muto (27), } \\
\text { Italy, } 1998 \\
\text { P,O } \\
\text { Subacute }\end{array}$ & $\begin{array}{l}93 \text { patients with low back and/or } \\
\text { sciatica, lasting two or more mos., } \\
\text { were treated with ozone }\end{array}$ & $\begin{array}{l}\text { The patients were divided into } \\
\text { two groups and all received ozone } \\
=15 \mathrm{~m} ; 30 \mu \mathrm{l} / \mathrm{mL} \text { intradiscal and } \\
\text { intraforaminal } \\
\text { G1(n35)with neurological deficit } \\
\text { G2(n=58) Without neurological } \\
\text { deficit }\end{array}$ & $\begin{array}{l}\text { Timing: } 6 \text { mos. } \\
\text { Measure } \\
\text { outcome } \\
\text { MacNab's } \\
\text { criteria }\end{array}$ & $\begin{array}{l}6 \text { mos. } \\
\text { (good or } \\
\text { excellent) } \\
\text { G1= } \\
\text { failure } \\
\text { in all } \\
\text { patients } \\
\text { G2= } \\
\text { success in } \\
77.58 \% \text { of } \\
\text { patients }\end{array}$ & - \\
\hline
\end{tabular}

$\mathrm{G} 1$ = group 1; G2 = group 2; G3 = group 3; G4 = group 4; $\mathrm{RA}=$ randomized; $\mathrm{P}=$ prospective; $\mathrm{O}=$ observational; $\mathrm{DB}=$ double blinded; $\mathrm{B}=$ blinded (patients or evaluator); R = retrospective; FBSS = failed back surgery syndrome; CT = tomography; VAS = Visual Analog Scale; ODI = Oswestry Disability Index; McGill = McGill questionnaire of pain; MacNab method (excellent and good outcome); RMDQ = Roland-Morris Disability Questionnaire; OPRS = Overall Patient Rating Scale; MRI/MR (magnetic resonance imaging); EMG (electroneuromyography).

The outcome parameters utilized in the observational studies were MacNab criteria $(29,32)$, VAS ( $26,31,33)$, ODI $(26,29)$, Roland-Morris (31), and Overall Patient Rating Scale (31). Three authors utilized CT/MRI in their follow-ups $(27,28,31)$ (Table 6).

\subsection{Effectiveness}

Overall, the observational studies revealed positive results for short- and long-term relief of pain. From the randomized studies, intervention was found superior to the control, with OR $2.66(95 \% \mathrm{Cl}, 1.94$ to 3.63$)$, and $P<$ 0.00001 as shown in Fig. 2.

These studies evaluated ozone applied at the paravertebral muscle and juxtaforaminal at the herniated disc level. Three of them compared ozone injections utilizing an active control group (steroid injections) $(14,15,16)$. Paoloni et al $(17)$ utilized a sham control group with a simulated injection that was administered using a false needle that pricked the skin without piercing it, applied at the lumbar paraspinal level, on the same site designed to reproduce the load sensation commonly described after $\mathrm{O} 2-\mathrm{O} 3$ injections.

\subsection{Level of Evidence}

The indicated level of evidence is II-3 for ozone therapy applied intradiscally and II-1 for ozone therapy applied paravertebrally on long-term relief in low back pain secondary to disc herniation (12).

\subsection{Recommendations}

Based on Guyatt et al (13), grading the strength of recommendations and quality of evidence in clinical guidelines, the recomendation is $1 \mathrm{C}$ for ozone therapy applied intradiscally and 1B for ozone applied at the paravertebral muscles or periforaminally.

\subsection{Complications}

Complications secondary to ozone therapy are rarely documented in the literature. In this review, regarding ozone therapy for low back pain, we encountered predominantly case reports of 5 different types of complications. Giudice et al (22) reported bilateral vitreo-retinal hemorrhages following ozone therapy for lumbar disc herniation. Furthermore, one case of thunderclap headache after oxygen-ozone therapy 


\begin{tabular}{|c|c|c|c|c|c|c|c|c|}
\hline \multirow[b]{2}{*}{ Study or Subgroup } & \multicolumn{2}{|c|}{ Experimental } & \multicolumn{2}{|c|}{ Control } & \multirow[b]{2}{*}{ Weight } & \multirow{2}{*}{$\begin{array}{c}\text { Odds Ratio } \\
\text { M-H, Fixed, } 95 \% \mathrm{Cl}\end{array}$} & \multirow{2}{*}{\multicolumn{2}{|c|}{$\begin{array}{c}\text { Odds Ratio } \\
\text { M-H, Fixed, } 95 \% \mathrm{Cl}\end{array}$}} \\
\hline & Events & Total & Events & Total & & & & \\
\hline Bonetti 2005 & 137 & 156 & 113 & 150 & $28.7 \%$ & $2.36[1.29,4.33]$ & & $\rightarrow-$ \\
\hline Gallucci 2007 & 61 & 82 & 36 & 77 & $19.5 \%$ & $3.31[1.70,6.45]$ & & $\longrightarrow$ \\
\hline Paoloni 2009 & 22 & 33 & 8 & 12 & $8.0 \%$ & $1.00[0.25,4.06]$ & & \\
\hline Zambello 2004 & 140 & 180 & 94 & 171 & $43.8 \%$ & $2.87[1.80,4.55]$ & & - \\
\hline Total $(95 \% \mathrm{Cl})$ & & 451 & & 410 & $100.0 \%$ & $2.66[1.94,3.63]$ & & $>$ \\
\hline Total events & 360 & & 251 & & & & & \\
\hline \multicolumn{7}{|c|}{$\begin{array}{l}\text { Heterogeneity: } \mathrm{Chi}^{2}=2.53, \mathrm{df}=3(\mathrm{P}=0.47) ;\left.\right|^{2}=0 \% \\
\text { Test for overall effect: } Z=6.13(\mathrm{P}<0.00001)\end{array}$} & $\begin{array}{ccc}0.01 & 0.1 & 1 \\
& \text { Favours control }\end{array}$ & \begin{tabular}{cc|}
10 & 100 \\
Favours experimenta
\end{tabular} \\
\hline
\end{tabular}

related to pneumoencephalus as a consequence of inadvertent intrathecal puncture was recently published (24). Ginanneschi et al (23) reported a case of a patient who experienced paresthesias along the anterolateral compartment of the left leg and hypoesthesia over the dorsum of the left foot, suggesting spinal nerve injury occurring a few minutes after percutaneous intradiscal infiltration of ozone for L4-L5 disc herniation. In 2004, Corea et al (21) published a report of vertebrobasilar stroke during ozone therapy. In 2 of 235 patients, Andreula et al (30) reported episodes of impaired sensitivity in the lower limb on the treated side, which resolved spontaneously within 2 hours. Fabris et al (34) reported a subcutaneous hematoma at the puncture site.

\subsection{Discussion}

The present review has added methodological improvements compared to previous review articles; the search database was wider and covered all languages, focusing on articles that used ozone alone in at least one group of patients. Final evidence was separated by the route of ozone administration. In addition, the authors performed a rigorous selection of RCTs that made possible a meta-analysis. Steppan at al (29) published a review in which data was extracted mainly from observational series; one was an unpublished study and one was a randomized trial on intradiscal ozone injections for the treatment of pain related to herniated discs. Although the authors have made a meticulous computation of data and wrote similar conclusions about the effectiveness and safety of this method, it probably would not be considered a meta-analysis if it had been submitted to the present review board.

Regarding the observational studies, 23 were initially selected according to the inclusion criteria, but only 8 could be included according to the rigorous methodological assessment criteria (11). Most studies lost points in the characterization of the study population because they did not specify the diagnosis. Probably, in future studies the authors should add diagnostic criteria and if needed, diagnostic procedures. The excluded studies also lack outcome measures and some of them had poor statistical analysis (which was absent in some of them). Furthermore, excluded studies contained heterogeneous populations of patients with low back pain, including patients with lumbar disc herniation, degenerative disease, acute pain, chronic pain, and patients with and without a history of operations. In addition, regarding the analysis of results, in some studies it was not clear what primary and secondary outcomes were expected; functional scales were diverse and in most cases not comparable. Most comparative studies used statistical analysis to aid the conclusions, but some of them have unacceptable confusion between normal and non-normal data distribution, resulting in the inappropriate choice of statistical tests. Furthermore, these studies often do not describe bias and limitations. Some studies include a large number of patients, a long period of follow-up and a careful surgical technique, but do not have appropriate design or statistical analysis (39). Another study did not compare with a method established in the literature, so it was excluded (46).

Among the selected RCTs, 3 of them compared ozone treatment with an active control group (steroid or steroid with local anesthetic) and one study compared ozone injection with a sham procedure. No placebo-control study was found among the articles included in this review. This seems to be a tendency when treatment-resistant pain is the issue. Currently, 
ethics committees seem to favor studies based in an active controls comparison group. In addition, this makes patient recruitment faster because patients have a better acceptance when there is no placebo involved. Although this is not a consensus, it seems logical that an established treatment is probably better than the placebo effect. So, if any new treatment is to be tested, it could be perfectly compared to an active control group and in this way the placebo effect would also be overcome. On the other hand, patients tend to think that new treatments are more efficacious than the established ones because of their novelty. This makes us think that the novelty usually carries a strong placebo effect. This controversy still keeps placebo-controlled trials as the gold standard methodology. However, in the near future this methodological recommendation will probably be reviewed because practical issues point to more progressive methodology for active control studies in pain literature.

Some of the studies have evaluated the morphology of the disc by MRI or CT scan during follow-up. Buric et al (31) evaluated the clinical and morphological results of patients with disc disease and observed that 15 of the 30 patients showed clinical improvement, performing post operative MRI imaging. Eight of these patients had a substantial reduction of over $50 \%$ in herniation volume. Two patients had a volume reduction of less than $50 \%$, whereas 5 patients had no substantial variation in herniation volume. Muto et al (27) observed a reduction in the size of the herniated disc in only 8 cases out of the 45 patients who had improved. In 2004, Muto et al (28) documented a reduction in herniated disc size in $63 \%$ of cases, confirming persistent satisfactory outcome. Thus, these authors stated that the equation large herniation = major symptoms, small herniation = minor symptoms, does not always hold true. It seems quite natural to assume that clinical signs and symptoms of disc herniation are not caused only by mechanical compression but that biochemical factors play an important role in inflammatory sensitization and immune response in the epidural environment of the nerve roots and ganglia. Based on the same reasoning, it seems logical to presume that mechanical removal of herniated tissue may not always be needed and that reducing the inflammatory process could essentially be sufficient to treat the symptoms. This hypothesis was partially confirmed by the cited study $(49,50)$. On the other hand, patients who were clear candidates for surgery had no improvement after ozone therapy. Muto et al (27) observed treatment failure in all 35 patients pre- viously selected for surgery who presented a herniated or protruded disc with radicular pain associated with neurological deficit. In the work of Buric (50), 2 patients dropped out of the ozone therapy group because of aggravating symptoms and were subsequently operated on. In another observational study (30), among patients treated with ozone and whose treatment had failed, outcomes were poor in $25 \%$ and poor with recourse to surgery in $4.7 \%$. Among the patients in the steroid group and anesthetic injection group, 50 (16.7\%) had poor results and $15(5 \%)$ were referred for surgery.

The majority of the studies reviewed included patients with discogenic disease at one or more levels between L3 and S1(14-16,26,27,29-31). However, other series included heterogeneous groups of patients with other primary nondisc diseases such as canal stenosis, postsurgical fibrosis (failed back surgery syndrome), disc protrusion with vertebral instability, facet arthrosis, calcified herniation, intervertebral osteochondrosis, and pseudoanterolisthesis. In the first group, positive results were achieved in $75-80 \%$ of treated patients. In patients with a nondisc disease, the rate of sustained improvement ranged between 44 to $70 \%$ in all groups, independent of the morphological classification of the spinal disease $(26,28,29)$. This suggests that ozone therapy may have an important role in low back pain relief, independent of the source of disease.

Ozone is a strong oxidizing agent that quickly reacts and oxidizes the proteoglycans in the nucleus pulposus, which results in a small reduction of disc volume and subsequently contributes pain relief. The suggested premise is that a small volume reduction results in a significant decrease in pressure. In addition, it has been shown to have anti-inflammatory/analgesic and natural antibacterial effects $(5,52)$. Additional discussion of ozone's mechanisms of action can be found elsewhere (51).

Ozone therapy for lumbar disc herniation is a procedure that is considered generally risk-free or as low as $0.1 \%(48)$ and has low or no adverse effects at concentrations used for therapeutic application (10-40 $\mu \mathrm{g} / \mathrm{mL})$. However, in the present review, 6 reports of side effects related to ozone infusion were found. Similar descriptions of transitory paresthesia suggested transient root dysfunction, although the mechanisms underlining the reported sensations are still not clear. Assuming the presence of microfractures of the annulus fibrosus, one possibility is that an abrupt, transient pressure spike in the region of the spinal canal and cerebrospinal fluid (CSF) pressure after disc infiltration could be related to 
the transient paraesthetic symptoms. A similar mechanism was postulated as the cause of acute bilateral intraocular hemorrhages after injection of the $02-03$ mixture (22). Concerning the pathophysiology of the lesion, it could be hypothesized that an abrupt and transient increase of CSF pressure causes focal damage by means of mechanical transmission of pressure in the CSF, manifesting in the form of direct root trauma. The occurrence of retinal hemorrhages immediately after rapid injection of air into the subarachnoid space during myelography or after epidural injection of corticosteroids has also been previously described $(52,53)$.

Infection secondary to oxygen-ozone injection therapy is extremely rare. Recently, Gazzeri et al (25) reported a case of fatal septicemia secondary to Escherichia coli infection after ozone therapy for lumbar disc herniation, in which a pyogenic lumbar muscle involvement and septic pulmonary embolism were present. The most likely pathophysiological mechanism in these cases was probably iatrogenic; that is, the direct inoculation of the bacteria by injections due to an inadequate asepsis procedure as has occurred in other percutaneous spinal procedures $(25,30)$.

\subsection{Conclusion}

This systematic review and meta-analysis of ozone therapy for low back pain secondary to herniated disc indicated the level of evidence is II-3 for ozone therapy applied intradiscally and II-1 for ozone therapy applied at the paravertebral muscle and periforaminally for long-term pain relief based on USPSTF criteria (12). The aviable evidence yielded a $1 \mathrm{C}$ strength of recommendation (13) for ozone therapy applied into the disc and $1 \mathrm{~B}$ for ozone applied at the paravertebral muscles or periforaminally. The evidence was derived from randomized control trials within this meta-analysis and observational studies. In addition, the low costs of ozone therapy may account for its wider use in the percutaneous treatment of herniated lumbar discs (54) and other causes of back pain. Injections can be repeated if necessary and complications or side effects are rare. Therefore, this method may be considered an option to treat lumbar disc herniation-related low back pain that has failed to respond to conservative treatment, representing an alternative to surgery. However, future studies are necessary to demonstrate whether ozone therapy effects persist over time.

\section{References}

1. Freynhagen R BR, Gockel U, Tölle TR. painDETECT: A new screening questionnaire to identify neuropathic components in patients with back pain. Curr Med Res Opin 2006; 22:1911-1920.

2. Kaki A M E-YAZ, Youseif E. Identifying neuropathic pain among patients with chronic low-back pain: use of the leeds assessment of neuropathic symptoms and signs pain scale. Reg Anesth Pain Med 2005; 30:422.e1-422.e9.

3. Cohen SP, Williams S, Kurihara C, Griffith $S$, Larkin TM. Nucleoplasty with or without intradiscal electrothermal therapy (IDET) as a treatment for lumbar herniated disc. J Spinal Disord Tech 2005; 18 Suppl:S119-24.

4. Postacchini F, Postacchini R. Operative management of lumbar disc herniation: The evolution of knowledge and surgical techniques in the last century. Acta Neurochir Suppl 2011; 108: 17-21.

5. Bocci VA. Scientific and medical aspects of ozone therapy. State of the art. Arch Med Res 2006; 37:425-435.

6. Manchikanti L, Boswell MV, Singh V, Benyamin RM, Fellows B, Abdi S, Buenaventura RM, Conn A, Datta S, Derby R, Falco
FJ, Erhart S, Diwan S, Hayek SM, Helm S, Parr AT, Schultz DM, Smith HS, Wolfer LR, Hirsch JA; ASIPP-IPM Comprehensive evidence-based guidelines for interventional techniques in the management of chronic spinal pain.Pain Physician 2009; 12:699802.

7. Manchikanti L, Benyamin R, Helm S, Hirsch JA. Evidence-based medicine, systematic reviews, and guidelines in Interventional pain management: Part 1: Systematic reviews and meta-analyses of randomized trials. Pain Physician 2009; 12:3572.

8. Moher D, Liberati A, Tetzlaff J, Altman DG, Group P. Preferred reporting items for systematic reviews and meta-analyses: the PRISMA statement. PLoS Med 2009; 6:e1000097.

9. Staal JB, De Bie RA, De Vet HCW, Hildebrandt J, Nelemans P. Injection therapy for subacute and chronic low back pain: An updated cochrane review. Spine 2009; 34:49-59.

10. Koes BW, Sholten RJPM, Mens JMA, Bouter LM. Efficacy of epidural steroid injections for low-back pain and sciatica: A systematic review of randomized clinical tri- als. Pain 1995; 63:279-288.

11. West S, King V, Carey TS, Lohr KN, McKoy N, Sutton SF, Lux L. Systems to rate the strength of scientific evidence. Evid Rep Technol Assess (Summ). 2002; 47:111.

12. Berg AO, JD. A. Introducing the third U.S. Preventive Services Task Force. Am J Prev Med 2001; 20:21-35.

13. Guyatt G, Gutterman D, Baumann MH, Addrizzo-Harris D, Hylek EM, Phillips B, Raskob G, Lewis SZ, Schünemann H. Grading strength of recommendations and quality of evidence in clinical guidelines: Report from an American College of Chest Physicians task force. Chest 2006; 129:174-81.

14. Bonetti $M$, Fontana A, Cotticelli B, Volta GD, Guindani M, Leonardi M. Intraforaminal $\mathrm{O}_{2}-\mathrm{O}_{3}$ versus periradicular steroidal infiltrations in lower back pain: Randomized controlled study. AJNRAm J Neuroradiol 2005; 26:996-1000.

15. Zambello A, Fara B, Tabaracci G, Bianchi $M$. Epidural steroid injection vs paravertebral $\mathrm{O}_{2}-\mathrm{O}_{3}$ infiltration for symptomatic herniated disc refractory to conventional treatment: A prospective random- 
ized study. Rivista di Neuroradiologia 2006; 5:123-127.

16. Gallucci M, Limbucci N, Zugaro L, Barile A, Barile A, Stavroulis E, Ricci A, Galzio R, Masciocchi C. Sciatica: Treatment with intradiscal and intraforaminal injections of steroid and oxygen-ozone versus steroid only. Radiology 2007; 242:907-913.

17. Paoloni M DSL, Cacchio A, Apuzzo D, Marotta S, Razzano M, Franzini M, Santilli V. Intramuscular oxygen-ozone therapy in the treatment of acute back pain with lumbar disc herniation. Spine 2009; 34:1337-1344.

18. Ansede Alonso JC, Contreras Joya M, Perez Hidalgo S. Prospective and randomized study in patients with low back pain or sciatic pain with ozonetherapy treatment. Patologia del Aparato Locomotor 2007; 5:46-54.

19. Wu Z, Wei LX, Li J, Wang Y, Ni D, Yang P, Zhang Y. Percutaneous treatment of noncontained lumbar disc herniation by injection of oxygen-ozone combined with collagenase. Euro] Rad 2009; 72:499-504.

20. Gautam S, Rastogi V, Jain A, Singh AP. Comparative evaluation of oxygen-ozone therapy and combined use of oxygenozone therapy with percutaneous intradiscal radiofrequency thermocoagulation for the treatment of lumbar disc herniation. Pain Practice 2011; 11: 160-166.

21. Corea F, Amici S, Murgia N, Tambasco N A case of vertebrobasilar stroke during oxygen-ozone therapy.] Stroke Cerebrovascular Diseases 2004; 13:259-261.

22. Giudice GL, Valdi F, Gismondi M, Prosdocimo $G$, Belvis V. Acute bilateral vitreoretinal hemorrhages following oxygenozone therapy for lumbar disk herniation. Am J Ophth 2004; 138:175-177.

23. Ginanneschi F, Cervelli C, Milani P, Rossi A. Ventral and dorsal root injury after oxygen-ozone therapy for lumbar disk herniation. Surgical Neurology 2006; 66:619620.

24. Chalaupka FD, Caneve G, Mauri M, Zaiotti G. Thunderclap headache caused by minimally invasive medical procedures: Description of 2 cases. Headache 2007; 47:293-295.

25. Gazzeri R, Galarza M, Neroni M, Esposito $S$, Alfieri A. Fulminating septicemia secondary to oxygen-ozone therapy for lumbar disc herniation. Spine 2007; 32:121-123.

26. Oder B, Loewe M, Reisegger M, Lang W, Ilias W, Thurnher SA. CT-guided ozone/ steroid therapy for the treatment of degenerative spinal disease: Effect of age, gender, disc pathology and multi-seg- mental changes. Neuroradiology 2008; 50:777-785.

27. Muto M, Avella F. Percutaneous treatment of herniated lumbar disc by intradiscal oxygen-ozone injection. Interventional Neuroradiology 1998; 4: 279-86.

28. Muto M, Andreula C, Leonardi M. Treatment of herniated lumbar disc by intradiscal and intraforaminal oxygen-ozone $\left(\mathrm{O}_{2}-\right.$ $\mathrm{O}_{3}$ ) injection. J Neuroradiol 2004; 31: 183-9.

29. Muto M, Ambrosanio G, Guarnieri G, Capobianco E, Piccolo G, Annunziata G, et al. Low back pain and sciatica: Treatment with intradiscal-intraforaminal $\mathrm{O}_{2}-\mathrm{O}_{3}$ injection. Our experience. Radiologia Medica 2008; 113:695-706.

30. Andreula C F SL, Santis F. Minimally invasive oxygen-ozone therapy for lumbar disk herniation. Am J Neuroradiology 2003; 24:996-1000.

31. Buric J, RM L. Ozone chemonucleosis in no-contained lumbar disc herniations: A pilot study with 12 months follow-up. Acto Neurochir Suppl 2005; 92: 93-7.

32. Xu L, Li ZL, He XF, Xiang DC, Ma J, Hong C), He JX, Yang L, Gong ZH, Qiu J. Evaluation of the clinical curative effect of an $\mathrm{O}_{2}-\mathrm{O}_{3}$ mixture to treat lumbar disc herniation with different treatment sessions. Interv Neuroradiol 2009; 15:159-163.

33. Das G, Ray S, Ishwarari S, Roy M, Ghosh P. Ozone nucleolysis for management of pain and disability in prolapsed lumber intervertebral disc a prospective cohort study. Interventional Neuroradiology 2009; 15:330-334.

34. Fabris G, Tommasini G, Petralia B, Lavaroni A, De Nardi F, De Luca G, et al. L'ossigeno-ozono terapia intra-foraminale. Rivista di Neuroradiologia 2001; 14: 61-66.

35. Paradiso R, Alexandre A. The different outcomes of patients with disc herniation treated either by microciscectomy, or by intradiscal ozone injection. Acto Neurochir Suppl 2005; 92: 139-142.

36. Romeo A, Cirillo F. Kinesiatrics and oxygen-ozone therapy for lumbosacral discroot compression. Rivista di Neuroradiologia 2001; 14:47-49.

37. Bonetti $M$, Cotticelli B, Albertini F, Brayda-Bruno M, Valdenassi L, Richelmi P. Percutaneous paravertebral ozone therapy. Rivista di Neuroradiologia 2002; 15: 415-419.

38. D'Erme M, Scarchilli A, Artale AM, Pasquali Lasagni M. Ozone therapy in lumbar sciatic pain. Radiol Med 1998; 95:21-24
39. Alexandre A, Coro L, Paradiso R, Dall'aglio R, Alexandre AM, Fraschini F, et al. Treatment of symptomatic lumbar spinal degenerative pathologies by means of combined conservative biochemical treatments. Acta Neurochir Suppl 2011; 108: 127-135.

40. Masini M, Calaca A. Minimally invasive treatment for refractory low back pain, targeted by epidural endoscopy with $\mathrm{O}_{2} / \mathrm{O}_{3}$ and steroid therapy. Acta Neurochir Suppl 2011; 108:33-37.

41. Donato AD, Fontana C, Pinto R, Beltrutti $D$, Pinto $G$. The effectiveness of endoscopic epidurolysis in treatment of degenerative chronic low back pain: A prospective analysis and follow-up at 48 months. Acta Neurochir Suppl 2011; 108:67-73.

42. Gjonovich A, Sattin GF, Girotto L, Bordin M, Gallo L, Preciso G. Lomabalgie ribelli: L'ossigeno-ozono terapia a confronto con altre metodiche. Rivista di Neuroradiologia 2001; 14:35-38.

43. Peng J, Xing $H$, Zhang B, Wu F, Guo $J F, \mathrm{He} Y K$, et al. Ozone injection for the treatment of lumbar disc herniation: A therapeutic analysis of 104 cases. Journal of Interventional Radiology 2010; 19:114116.

44. Zhang L, Li JK, Chen ZH, Sun XJ, Liu JP. CT-guided intradiscal ozone injection combined with intervertebral facet joint steroid injection for lumbar disk herniation accompanied with intervertebral arthritis. Journal of Interventional Radiology 2009; 18:853-855.

45. Peng J, Xing H, Zhang B, Wu F, Guo J, He X. Analysis of the efficacy of ozone therapy on lumbar disc herniation. International Journal of Ozone Therapy 2009; 8:206-210.

46. Vetro A, Mantia F, Mantia R. Terapia dei confliti disco-radicolari. Comparazione clinica tra ossigeno-ozono terapia paravertebrale e trattamento combinato ossigeno-ozono terapia e un prodotto a base di acido alfa-lipoico (ALAnerv). Minerva Ortop Traumatolol 2006; 57:57-63.

47. Baabor MG, Vázquez PF, Sánchez JA. Automated nucleotomy and nucleolysis with ozone. Acta Neurochir Suppl 2011; 108:97-101.

48. Steppan J MT, Muto M, Murphy K J. A Metaanalysis of the effectiveness and safety of ozone treatments for herniated lumbar discs. J Vasc Interv Radiol 2010; 21:534-548.

49. Koike Y, Uzuki M, Kokubun S, Sawai T. Angiogenesis and inflammatory cell 
infiltration in lumbar disc herniation. Spine 2003; 28:1928-1933.

50. Peng BG, Hao J, Hou S, Wu W, Jiang D, Fu X, Yang Y. Possible pathogenesis of painful intervertebral disc degeneration. Spine 2006; 31:560-566.

51. Borrelli E. Mechanism of action of oxy- gen ozone therapy in the treatment of disc herniation and low back pain. Acta Neurochir Suppl 2011; 108:123-125.

52. Kushner FH, Olson JC. Retinal Hemorrhage as a consequence of epidural steroid injection. Archives of Ophthalmology 1995; 113:309-313.
53. Oberman J, Cohn H, Grand MG. Retinal complications of gas myelography. Archives of Ophthalmology 1979; 97:19051906.

54. Andreula C, Muto M, Leonardi M. Interventional spinal procedures. European Journal of Radiology 2004; 50:112-119. 